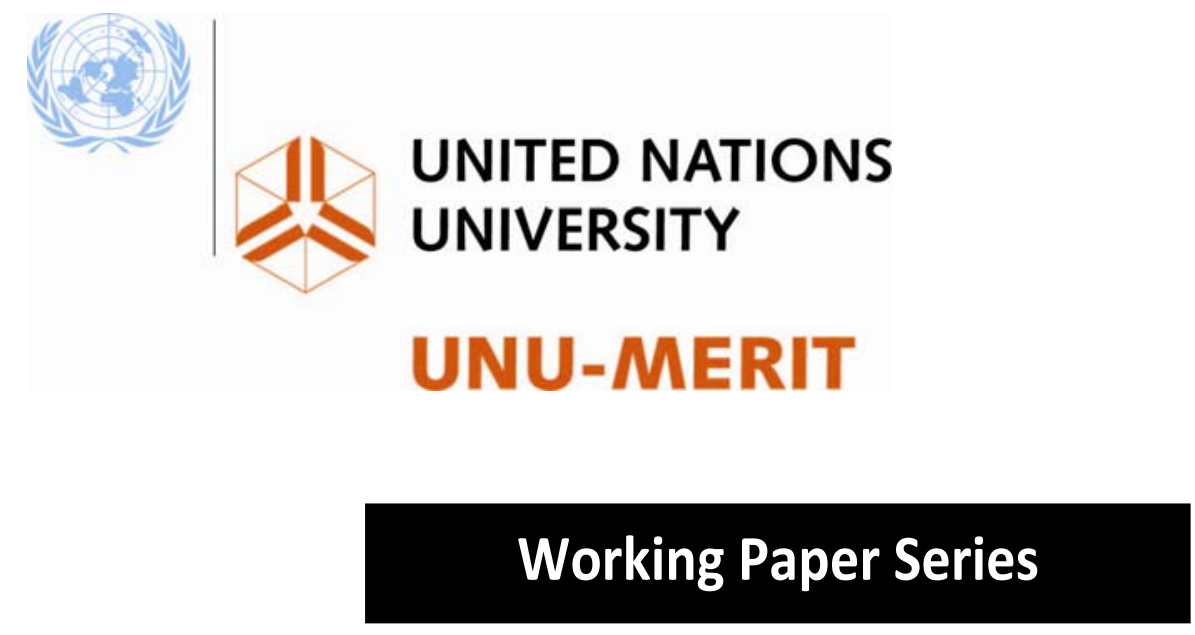

\#2012-025

Open innovation, contracts, and intellectual property rights: an exploratory empirical study John Hagedoorn and Ann-Kristin Ridder

Maastricht Economic and social Research institute on Innovation and Technology (UNU-MERIT) email: info@merit.unu.edu | website: $\underline{\text { http://www.merit.unu.edu }}$

Maastricht Graduate School of Governance (MGSoG)

email: info-governance@maastrichtuniversity.nl | website: http://mgsog.merit.unu.edu

Keizer Karelplein 19, 6211 TC Maastricht, The Netherlands

Tel: (31) (43) 388 4400, Fax: (31) (43) 3884499 
UNU-MERIT Working Papers

ISSN 1871-9872

Maastricht Economic and social Research Institute on Innovation and Technology, UNU-MERIT

Maastricht Graduate School of Governance

MGSoG

UNU-MERIT Working Papers intend to disseminate preliminary results of research carried out at UNU-MERIT and MGSoG to stimulate discussion on the issues raised. 
OICIPR 29.03.2012

\title{
Open innovation, contracts, and intellectual property rights: an exploratory empirical study
}

\author{
John Hagedoorn \\ Ann-Kristin Ridder \\ Department of Organization \& Strategy and UNU-MERIT \\ School of Business and Economics \\ Maastricht University \\ PO Box 616, 6200 MD Maastricht \\ The Netherlands \\ Telephone: (31)43-3883823 \\ Fax: (31)43-3216518 \\ Email: j.hagedoorn@maastrichtuniversity.nl \\ a.ridder@maastrichtuniversity.nl
}

The authors thank Henry Chesbrough, Myriam Cloodt, Wilko Letterie and seminar participants at Maastricht University, University of Mannheim, and RWTH Aachen University for their comments and useful suggestions. The authors also thank Wim Vanhaverbeke for supporting the data collection via Exnovate. 


\title{
Open innovation, contracts, and intellectual property rights: an exploratory empirical study
}

\author{
Abstract \\ Our exploratory empirical study, based on a series of in-depth interviews and a survey of \\ firms, searches for answers on a number of questions that deal with the role of formal \\ contracts and intellectual property rights in the context of open innovation. We find that firms \\ active in open innovation have a strong preference for the governance of their open \\ innovation relationships through formal contracts. These contracts are relevant from both a \\ control and a process monitoring perspective. Also, despite the open nature of open \\ innovation, firms still see intellectual property rights as highly relevant to the protection of \\ their innovative capabilities. In a first attempt to explain this preference for intellectual \\ property rights by open innovation firms, we find the degree of openness of firms, their \\ legalistic attitude, and the competitive dynamics of their product market environment to be \\ related to this preference. \\ (144 words) \\ JEL codes: K11, K12, L24 \\ Keywords: open innovation, contracts, intellectual property rights
}




\section{Introduction}

Globalization, increasing technological complexity and a variety of other environmental, strategic, and economic factors have forced firms to shift their focus from closed innovation, which relies primarily on the internal development and application of new technologies, to a model of ‘open innovation’ (Chesbrough, 2003; Christensen, Olesen, and Kjaer 2005; Lichtenthaler and Ernst, 2009). While the traditional closed innovation model is based on a logic of internal focus and control, the open innovation model suggests that firms increasingly open up their boundaries (Dahlander and Gann, 2010), access external sources of knowledge and technology (Fey and Birkinshaw, 2005), and bring in-house inventions to markets via external paths (Lichtenthaler, 2008). Hence, firms that are adopting an open innovation model, embrace a mentality of outside-in and inside-out thinking that builds extensively on external sources of innovation and commercialization (Chesbrough, 2003, 2006a;

Lichtenthaler and Lichtenthaler, 2009). As such, the core idea of open innovation refers to the exchange of knowledge of firms with a diversity of external sources (firms such as competitors, customers, start-ups, and suppliers, and universities and a range of other organizations and institutions) through different mechanisms (collaborative R\&D, corporate venturing, crowdsourcing, licensing, etc.) (Grimpe and Sofka, 2009; Laursen and Salter, 2006).

This transformation of the innovation model from a closed to an open model creates a number of new strategic challenges. Two of the main challenges refer to the governance and control of cooperative innovation processes and the management of the intellectual property of diverse parties (Enkel, Gassmann and Chesbrough, 2009; Graham and Mowery, 2006; West, 2006). By opening up its boundaries, the focal firm might lose some control over its resources and operations and is, therefore, likely to incur increased coordination costs (Almirall and Casadesus-Masanell, 2010; Enkel, Gassmann, and Chesbrough, 2009). The 
governance of inter-organizational relationships through formal contracts and intellectual property rights (IPR) are, thus, seen as critical topics in the current debate about open innovation as they are both of strategic importance to open innovation firms (Chesbrough, 2003; 2006a,b). Contracts that firms use to formalize their relationships with these external sources of innovation are defined as legally binding agreements, in writing, between two or more parties (in this context firms) that are intended to create a legal obligation or a set of obligations. IPR refer to exclusive privileges granted to owners of a variety of distinct new creations in terms of intangible assets (discoveries, inventions, and new designs). Common types of IPR include patents, trademarks, copyrights, design rights, and technical or commercial information (trade secrets).

As discussed further below, most of the debate on open innovation, contracts, and IPR is still largely phrased in general terms. Little is known about the specifics of how open innovation firms govern their relationships with partners through contracts and how important IPR are when these open innovation firms collaborate with others. Not only do most contributions to the open innovation literature discuss governance and IPR in rather general terms (e.g. Dahlander and Gann, 2010; Huizingh, 2011), the debate is also largely based on some general assumptions about the behaviour and strategy of open innovation firms with little or no systematic analysis of the actual choices that these firms make when it comes to contracts and IPR in their dealings with other firms and organizations.

The main objective of our contribution is to explain the relevance of contracts and IPR for open innovation, based on our perception of the relevant literature, and to extend this understanding with an exploratory empirical study of the preferences of open innovation firms. In the following, we first picture the role of contracts and IPR in the context of open innovation, based on a survey among open innovation firms complemented by in-depth qualitative field research on a small number of leading open innovation firms. This part of our 
paper is largely guided by a set of questions regarding the preference of open innovation firms for contracts while cooperating with open innovation partner firms, the relevance of these contracts from a legal and a more practical perspective, and the relevance of various elements of IPR for open innovation inter-firm partnerships. ${ }^{1}$ These research questions are placed in the context of a dichotomy in the extant literature where some contributions take a formal perspective that stresses the importance of control through contracts and IPR, whereas others emphasize the role of open, informal exchange between open innovation partners where contracts and IPR are of little or no relevance. Although still very much within the exploratory framework of our research, the second part of our empirical analysis is to be seen as a first attempt to analyse some crucial firm and industry characteristics associated with the importance of IPR in open innovation. In that context, the degree of openness of firms, their legalistic attitude in terms of the importance of contracts for their business model, and the competitive dynamics of their product market environment are associated with the preference for IPR.

The next section explains the various aspects of our exploratory empirical research in terms of both the field research and the survey that jointly build the core of the empirical basis for this paper. This is followed by sections on open innovation and contracts and open innovation and IPR that discuss the various findings of our field research and survey against the background of the current debate in the open innovation literature. After these descriptive sections, we continue with the preliminary explanation of the preference for IPR by open innovation firms. The final section refers to the discussion of our findings, their limitations, and some conclusions. 


\section{Research strategy: field research and survey}

For our data collection we applied two, methodologically and chronologically distinct methods that follow a two-phase design with separate qualitative field research and a quantitative survey of firms (see Creswell and Plano-Clark, 2007). During the period January - February 2011 we conducted a series of interviews with representatives of five large firms that can be seen as open innovators. We selected these firms on the basis of several criteria. In a first step, we screened websites of leading open innovation practitioner conferences held in 2010 (including NineSigma Open Innovation Leadership Summit, Open Innovation Conference in Frankfurt, European Innovation Conference [Open Innovation and New Business Creation Track], Marcus Evans Annual Innovation Excellence, and the CoDevelopment and Open Innovation Conference). Based on this screening, we generated a list of firms that participated in several of these conferences. We contacted a number of firms from this list that are located within our geographical proximity. Five of these firms agreed to participate in our study. In a second step, prior to conducting the interviews, we ensured that these firms can be classified as 'open innovators', by applying the following criteria. First, we analysed their annual reports; four out of the five firms explicate in their annual reports that they rely on open innovation as a strategic approach to managing their innovation processes. Second, all of these firms state on their corporate websites that they implement open innovation strategies, processes, and tools. Finally, all five firms have had articles on the topic of open innovation published in trade journals and are classified as open innovation firms in academic papers. In sum, based on these criteria, we can be quite confident that the selected firms engage extensively in open innovation and are therefore relevant for our research questions.

In terms of their industry background, these five firms are found in electronics, chemicals, and telecommunications. On average, the interviews took about two hours. The 
representatives of these firms can be characterized as senior management responsible for $R \& D$ and open innovation. The interviews focused on a variety of questions related to firm innovative capabilities, $R \& D$ and innovation strategy, inter-firm cooperation, open innovation, contracts, and IPR. Given the exploratory nature of our research, we used a semistructured interview guideline with a list of main questions that reflect the focus of our research but the interviews also allowed for enough freedom for both the interviewer and the managers to elaborate on particular subjects that both thought interesting enough to explore further. Each interview was recorded and later transcribed into 234 single-spaced pages of interview material. The primary function of these interviews was twofold: first to provide us with a better understanding of the basic thoughts behind open innovation as practiced by some of the leading open innovation firms and second to give us qualitative information about the role of contracts and IPR in the day-to-day practice of open innovation. The qualitative interviews facilitate our survey research by providing background information and generating richer details on the role of contracts and IPR in open innovation (Miles and Huberman, 1994; Punch, 2005). Hence, we use an embedded research design, in which the qualitative interview data plays a supplemental role to our survey data (Creswell and Plano-Clark, 2007). In the following, we will report on the insights from these interviews when we add some of this qualitative information to the more quantitative information from our survey research. Throughout this paper, we will refer to this part of our research as ‘field research' and, given the expected anonymity, not refer to the specific firms and managers we interviewed.

The larger part of our data collection is based on a survey that used the key informant method to collect data at the firm level for a larger group of firms active in open innovation. That data collection was organized via 'Exnovate', the European Network of Excellence on Open and Collaborative Innovation. This network is a European hub for knowledge exchange on collaborative forms of innovation. Firms that participate in this platform source external 
knowledge and technologies by means of open innovation, which makes them relevant to our research questions. The Exnovate network consists of about 850 firms from a range of countries. Belgium, The Netherlands, UK, and USA are countries that host relatively large numbers of firms affiliated with this network. Exnovate allowed us to directly address key informants from these firms involved in external knowledge sourcing and open innovation. These key informants hold positions such as R\&D manager, innovation director, open innovation manager, or CTO. On average, these key informants have been working for their firm for 13 years which suggests a high level of experience and knowledge about firm strategies and processes.

Our survey was designed and implemented according to Dillman’s (2007) tailored design method. In order to improve our scale items and enhance the validity of the questionnaire, we extensively pre-tested our survey. First, face-to-face interviews were conducted with six academics to discuss the appropriateness of measurement items. In addition, the survey was pilot-tested with eleven open innovation managers. The managers were asked to fill out the questionnaire and to indicate any wording of the items that they thought were ambiguous. In addition, they were invited to provide suggestions for improvement of the questionnaire. In refining the questionnaire, special care was taken to ensure that the measures were applicable to managers, while still capturing the measures’ theoretical concepts.

At the start of the actual survey, invitation e-mails were sent, explaining the study's purpose and requesting participation. The e-mail was carefully constructed to achieve authority and credibility. This includes assuring that responses would be treated confidentially and that results are only reported in aggregate form. In addition, as an incentive, respondents were offered a customized report that summarizes the results of the study. Finally, transparency regarding the researchers, contact information, and sampling 
methodology was provided. Respondents were asked to click on the URL link provided in the e-mail message, which linked to an online survey instrument. To reduce the potential for social desirability bias, respondents were given explicit instructions to reflect the actual situation in their firm. During the period April-May 2011, five rounds of contacts were made via e-mail, which yielded 86 responses. This corresponds to a response rate of about $10 \%$.

We tested nonresponse bias using analysis of variance techniques. The first and last twenty-five per cent of respondents ( 20 cases each) were compared on key variables for open innovation (the importance of IPR, the importance of contracts for controlling and monitoring, and openness in terms of different knowledge sources) and firm characteristics (size, age, R\&D intensity). The analysis indicated that the two groups are statistically similar on all variables. Hence, nonresponse bias does not seem to pose a problem in this study.

Furthermore, as this study relies on single respondents for collecting firm-level data, common method bias may distort our results. Several steps helped to reduce this bias. First, a number of procedural remedies were employed, such as improving scale items via interviews and pre-testing, protecting respondent anonymity, ensuring subjects there were no right or wrong answers, and counterbalancing question order (Podsakoff, MacKenzie, Lee, and Podsakoff, 2003). In addition, statistical tests were conducted ex post to verify the quality of the survey data. We used the Harman's one-factor test by conducting an exploratory factor analysis on all variables used in the study. A principal components factors analysis reveals that there are nine factors with an eigenvalue greater than 1 , which together account for about $80 \%$ of the total variance. The extraction of several distinct factors combined with the relatively low amount of variance explained by the first factor (31\%) suggests that the data do not suffer from common method variance (Podsakoff, MacKenzie, Lee, and Podsakoff, 2003).

Given the current fatigue of firms and managers regarding surveys and the level of complexity of our survey instrument with very few yes/no questions, the current response rate 
appears the maximum we could reach after five rounds of contacts. In the end, this response rate leaves us with a relatively small sample. However, given the exploratory nature of our study, the interesting results and the quality of information, we are confident that the results presented below provide interesting new insights into a number of research questions regarding open innovation that so far have not, or only to a limited extent, been covered by empirical research.

\section{Industry and firm-size characteristics of the sample}

Three distinctive industries (chemicals, electronics, and business services) seem to be wellrepresented in our sample with a combined share of slightly over $60 \%$, see table 1 . Given the emphasis in our study on innovation and knowledge sharing, we also find, as in many other studies, that manufacturing industries are over-represented with a combined share of nearly $80 \%$. Due to missing or unclear information, about $8 \%$ of the firms that participated in our survey could not be identified in terms of their industry background.

\section{----- insert table 1 about here -----}

Large firms are well-represented in the initial group of Exnovate firms, which is also reflected in the size distribution for the firms in the actual sample (see table 2). Very large firms (with more than ten thousand employees) account for more than $65 \%$ of the sample. Small and medium sized firms, those that employ less than a thousand employees, reach a share of only close to $21 \%$ of our sample. This distribution is different from those found in studies on 'internal' innovation activities of firms such as those based on European CIS studies and US NSF studies where we find that, depending on where we draw the line, small and medium sized firms reach a share of close to $90 \%{ }^{2}$ Given the complex nature of open 
innovation where firms not only engage in internal innovative activities but also interact with various external innovation partners, we can expect that, on average, larger firms, rather than small and medium-sized firms, have the resources to implement open innovation strategies (Chesbrough, 2003). Recent empirical research confirms that most open innovation adopters are larger firms (Bianchi, Cavaliere, Chiaroni, Frattini, and Chiesa, 2011; Keupp and Gassmann, 2009; Lichtenthaler and Ernst, 2009). For many small and medium sized firms we anticipate that open innovation strategies with complex interactions with a variety of partners are much more difficult to implement (Kirschbaum, 2005). Even though the potential of open innovation in a small and medium sized firms context has recently been stressed, these firms still rely more on internal and public information instead of using information from competitors, customers, suppliers, and other firms in their innovation process (Lee, Park and Park, 2010). Hence, compared to the 'normal’ innovation - firm size distribution, we are expected to find fewer medium sized firms and in particular fewer small firms that pursue an open innovation strategy (see also De Backer, López-Bassols, and Martinez, 2008).

----- insert table 2 about here -----

\section{Open innovation and contracts}

Chesbrough’s seminal contributions (Chesbrough, 2003; 2006a,b) already stressed the importance of strategically managing open innovation where firms exchange their knowledge with a range of external partners. His acknowledgement that open innovation can be too open and that there is a risk of appropriation of innovative efforts by others (Chesbrough, 2006b) suggests that protection of innovative capabilities, not only through IPR protection but also through contractual relations with partners, might be unavoidable (see also Luoma, Paasi, and Volkokari, 2010). Some recent contributions pay more explicit attention to the use of 
contracts in open innovation. Munsch (2009) stipulates that given the uncertainty surrounding open innovation efforts, contracts have to be negotiated between open innovation partners to govern ownership, resource commitment, IPR, exclusivity, termination conditions and termination rights. In other words, firms active in open innovation would face all the contractual intricacies that play a role in standard inter-firm exchanges. Lee (2009) and Lee, Nystén-Haarala, and Huhtilaienen (2010) also stress the role that inter-firm contracts and firms' contracting capabilities should play in open innovation to establish ownership and to control appropriation and contingencies. Interestingly, these authors add that, given the dynamic nature of open innovation, these open innovation contracts will to a large extent remain incomplete and subject to what we could refer to as flexible private ordering (see also Almirall and Casadesus-Masanell, 2010).

Others have criticized this understanding of open innovation that embraces inter-firm contracting and which is still largely based on Chesbrough's original contributions. These critical contributions stress that open innovation should refer to the open disclosure of knowledge and sharing of this knowledge with all possible parties interested (Pénin, 2011; von Hippel and von Krogh, 2006). For instance, Pénin (2011) states that contract-based forms of inter-organizational collaboration, such as licensing, joint ventures, and contractual alliances, are according to this alternative view on open innovation not to be considered as part of a truly open innovation effort as these contractual collaborations usually restrict knowledge diffusion to the parties involved and certainly to third parties. Von Hippel and von Krogh (2006) mention that open innovation should be characterized by 'free revealing of product and process designs' that is available to all relevant firms and organizations. Or, as stated by Baldwin and von Hippel (2011, p. 1400): “... innovation is ‘open’ (...) when all information (...) is a public good - non-rivalrous and non-excludable.” The ultimate consequence of this particular understanding of open innovation is that innovation becomes 
open only if relevant knowledge can be shared by everyone and also becomes available to everyone, with little or no role for contracts. Interestingly, the basic thoughts behind this particular perception of open innovation seems to resonate the 'business world without contracts' of Macaulay (1963) where formal contracts are of little relevance and where, even if contracts are written, the interaction of firms is largely based on handshakes and trusted relationships and contracts are little more than afterthoughts or documents that disappear into a drawer.

There have been some attempts to integrate or reconcile the conflicting perspectives on open innovation and the role of contracts, presented in the above. Henkel (2006) suggests that through 'selective revealing' in open innovation processes, firms can benefit from open innovation by striking the right balance between sharing on the one hand and control and protection on the other. Dahlander and Gann (2010) suggest that open innovation can be disentangled with respect to pecuniary versus non-pecuniary processes. Non-pecuniary open innovation does not require any immediate financial rewards and involves free and selective revealing. Pecuniary open innovation does involve more formal control and protection, using contracts for licensing and the acquisition of expertise.

Given these different perspectives on control and the use of contracts in open innovation, the first and obvious question is whether firms, that perceive themselves as typical representatives of open innovation, do indeed use contracts in their open innovation collaboration, or not? More specifically, in our survey, we asked firms whether they used formal contracts in their collaborative innovative activities (R\&D, product and process development, and /or new designs) with their open innovation partner firms. Interestingly, our findings indicate that an overwhelming majority of firms in our sample, i.e. $94.2 \%$, do use formal contracts when working with their open innovation partner firms. Very few firms (5.8\%) rely on non-contractual partnerships for their open innovation activities. 
Our field research also indicates that open innovation firms prefer to use formal contracts with their open innovation partner firms. As stated during one of the interviews: “... whenever we get into a partnership or collaboration, there is a framework agreement..." Also, firms seem less inclined to engage in free revealing, as pointed out by another manager: "... I mean nothing is free in the world. It is open innovation; it is certainly not free... So who owns what in an open context? ...We have agreements and contracts on how to do this..." These formal contracts are often preceded by term sheets to stipulate preliminary terms and conditions that govern the joint activities of the open innovation partner firms. These term sheets help the firms to specify expectations of both parties and to speed up the contracting process. As explained by one of the managers: “... it is very important to get the right expectations from both sides at the beginning; before you develop a contract. What normally works best, is that you first have a term sheet on the expectations from both sides before you involve the lawyers to come up with a joint development agreement, or whatever kind of agreement. Otherwise it can take ages before you come to an agreement. So you should agree on terms first and then discuss the details later..." These terms sheets serve as a first basis for negotiations, prior to the development of a more formal final contract. As illustrated by the following quote: “... we make a term sheet, specifying what is mine, what is yours, and what we develop together..."

Similar to other formal inter-firm contracts, these open innovation contracts contain a range of contractual clauses, that refer to, amongst others, ownership, exclusivity, and financial compensation. However, in light of the dynamics of open innovation with frequent environmental changes as new partners and new $R \& D$ projects enter the picture, managers who we interviewed stressed that these contracts are expected to have a limited time horizon. This situation calls for what we described in the above as flexible private ordering through contracts. As mentioned by one of the managers, this implies that even if particular open 
innovation partners continue to cooperate over an extended period of time “... contracts are not perpetual, so contracts run for a couple of years and then they have to be renewed ...."

Extending our analysis of the role of contracts in open innovation, it is important to note that contracts can be used from a more legal perspective to control the progress of collaboration with partners as well as to monitor the progress of collaboration from a more practical process perspective (see also Argyres and Mayer, 2007; Mellewigt, Madhok, and Weibel, 2007; Reuer and Arino, 2007). This suggests the question to what extent both perspectives are relevant in the context of these open innovation cooperation contracts or whether open innovation firms see these contracts as primarily serving one goal. In other words, to what extent are these contracts used to monitor the process of open innovation cooperation process or to contractually control the cooperation with open innovation partners?

Our findings show that firms active in open innovation see both the legal (control) perspective and the practical (monitoring) perspective as quite relevant. On average, firms in our sample perceive contracts as an important legal mechanism to control their collaboration with open innovation partners, as indicated by an average score of 5.42 on a 7 point Likert scale (see table 3). The perceived importance of formal contracts as a means to monitor the progress of collaboration is somewhat lower with an average score of 5.10 on a 7 point Likert scale. These different scores for the use of contracts for control or monitoring purposes turned out to be only marginally statistically significant. ${ }^{3}$

----- insert table 3 about here -----

In sum, firms active in open innovation seem to have a very strong preference for (renewable) contracts to govern their relationship with their partners when they engage in joint $R \& D$, joint product and process development, and joint design. Not using contracts is 
very much rather the exception than the rule. Also, open innovation firms value these contracts from both a legal control perspective as well as a more practical process monitoring perspective.

\section{Open innovation and IPR protection}

As with the literature on the role of contracts in open innovation, there is a relatively small body of literature that pays explicit attention to the role of IPR (patents, trademarks, copyrights, design rights, and trade secrets in terms of technical or commercial information) in open innovation. Interestingly, these contributions seem to follow a divide somewhat similar to the debate about contracts, with some authors advocating the advantages of IPR protection for firms active in open innovation, whereas others stress the tension between IPR and open innovation. Sandulli and Chesbrough (2009), extending Chesbrough (2006b), stress that IPR can play a role in open innovation to ensure that firms can capture value from their innovative activities. Even more explicit are Pisano and Teece (2007) in their understanding of the role of strong regimes of appropriability where IPR protection facilitates the exchange of knowledge between firms as they realize that, given IPR, their intangible assets are difficult to imitate or appropriate. This understanding is shared by Graham and Mowery (2006) who suggest that “... IP protection creates a platform for the transfer of knowledge assets...” (p. 185). They argue that Chesbrough's concept of open innovation relies heavily on markets for intellectual capital that need to be supported by strong formal IPR (see also Dubiansky, 2006).

Pénin (2011) on the other hand stresses that IPR protection might threaten open innovation as broad accessibility of knowledge and technology is a crucial element of open innovation. In order to ensure this accessibility, IPR should not transfer control to a single owner but should take the form of 'copyleft' as found in open source software (De Laat, 2005;

von Hippel and von Krogh, 2003). ${ }^{4}$ Using IPR in a copyleft fashion would ensure that no firm 
can appropriate any innovation or its future improvements and as such this would preserve the openness of open innovation. West (2006) appears to take a position somewhere in between a pro and a counter-IPR argument. On the one hand, he acknowledges that IPR enable firms active in open innovation to capture returns on their innovative efforts while also secure their exchange with other firms. On the other hand, IPR protection may conflict with a common understanding of openness through which shared external information is without significant costs to partners.

Given these different perspectives on open innovation and IPR protection, it is an interesting question whether firms, that perceive themselves as typical representatives of open innovation, see IPR as a relevant protection mechanism for their innovative capabilities. During our field research, it was stressed by every manager we interviewed how important 'exclusivity based on patents and other intellectual property' and 'protection of knowledge' are for these open innovation firms. These firms indicate that, without IPR, they would be less inclined to cooperate with other firms as, based on their IPR protection, they are willing to invest in innovative activities that they can share with others.

Results from our survey show a more detailed perspective on the role of IPR. It turns out, see table 4, that patents and technical and commercial information (trade secrets) are seen as the most important instruments to protect the innovative capabilities of firms from their open innovation partners, as indicated by nearly $90 \%$ of the firms in our sample. Trademarks and design rights are also seen as relevant by a substantial share of firms (nearly $75 \%$ and over 65\%, respectively). Given the industry breakdown of the firms in our sample, it is probably not surprising that a smaller share of firms (about 53\%) see the relevance of copyrights for the protection of their innovative capabilities.

----- insert table 4 about here ----- 
These findings are in line with our field research which indicates that firms see IPR as sensitive and crucial to their open innovation strategy. The interviews show that there is a general preference for establishing clear ownership of IPR in an open innovation context. As mentioned by one of the managers: “... for us it is really important that if we do something, we have the right to do so. When we discuss collaboration, IPR are a very, very important point. Typically, we would like to own the IPR ...”

During the interviews, it was also frequently mentioned that IPR enable firms to share knowledge with other firms and the more protected their knowledge through IPR, the more they would be willing to collaborate. This protection of knowledge and innovative capabilities by means of IPR also enables firms to selectively exchange knowledge and share their innovative activities with certain partners. As pointed out by one of the managers: “... we are doing open innovation, not public innovation. Our goal is not to come up with results that we share with the rest of the world. Our goal is to come up with results that we share with some partners and that we keep secret for others ..."

A manager of another firm mentioned the importance of restricted technical and commercial information sharing where in order to protect its knowledge his/her firm uses compartmented information systems for knowledge sharing with its open innovation partners where not all partners have access to all information. Information is shared depending on the specific nature of the relationship. Interestingly, this competitive and protective setting for the role of IPR in open innovation was also stressed in yet another interview. In that case, the firm would routinely evaluate the IPR portfolio of its potential partner before the start of a joint open innovation project and examine whether any of the patents and trademarks of a potential partner would infringe on the firm's existing IPR or on those of other firms. In other words, the firm would assess whether and to which degree a potential open innovation partner 
would indeed possess certain IPR, relevant in the context of a joint open innovation project. Moreover, in case a potential open innovation partner possesses IPR that significantly overlaps with the focal firm's knowledge base, the open innovation collaboration may be reconsidered "...because in the end it makes it unclear who owns what and that gives us more trouble than it is worth in absorbing the outside technologies..."

The relevance of IPR not only indicates the degree to which firms expect them to play a role as a defensive appropriability mechanism, the relevance of IPR for firms can also refer to the degree to which IPR are used or perceived as signals of innovative capabilities (Cohen, Nelson, and Walsh, 2000; Hall, Jaffe, and Trajtenberg, 2005). According to Alexy, Criscuolo, and Salter (2009), IPR are even more beneficial to open innovation firms when they are used as a signal of innovative capabilities rather than as control rights. In that case, IPR can play a role for firms in drawing attention from (potential) partners. Managers interviewed during our field research mentioned that the degree to which firms are willing to protect their knowledge also indicates the value of that knowledge and that makes it attractive to work with these firms. As stated by one of them, when stressing the importance of IPR-backed knowledge for finding interesting partners: “... if this knowledge is not protected, it probably does not have any value, not for us, and not for anyone else ...”. Hence, cooperating with open innovation partner firms that do not value their IPR would make little or no sense.

Our survey findings suggest that also in this context of IPR as a signal of innovative capabilities, patents and technical and commercial information (trade secrets) are seen by firms as most important for their open innovation activities, as indicated by nearly $80 \%$ of the firms in our sample, see table 4. Trademarks and design rights are also seen as relevant signals of innovative capabilities by a substantial share of firms. Trademarks score $61 \%$, design rights reach a score of about 54\%. Again, given the industry breakdown of our sample, 
it is not surprising that a relatively small share of firms (nearly 40\%) see the relevance of copyrights for signalling purposes.

When we take a closer look at the relative importance of these different IPR for both protection and signalling in the context of open innovation, we also see that on average patents and technical and commercial information (trade secrets) are perceived as the most important IPR, see table 5. Yet, the other IPR (trademarks, design rights, and copyrights) still appear to be quite important as well, both for protection and signalling purposes.

---- insert table 5 about here -----

The above suggests that although we can debate the degree to which in theory IPR limit the openness of open innovation, in practice firms that are active in open innovation do seem to value IPR. In particular, patents and technical or commercial information (trade secrets) are seen by nearly $90 \%$ of the firms as relevant appropriability mechanisms that also turn out to be perceived as important for the protection of innovative capabilities. Although, contrary to the expectations of e.g. Alexy, Criscuolo and Salter (2009), IPR as signals of innovative capabilities on average score somewhat lower than for protection purposes, these IPR do seem to play a relevant role as signals of innovative capabilities for firms active in open innovation.

\section{A preliminary explanation of the preference for IPR by open innovation firms}

What we have seen so far indicates that open innovation firms have a very strong preference for contracts to control their exchange of knowledge with their open innovation partners. Concerning the relevance of IPR for open innovation firms, the above suggests quite some variation in the preference of firms for different aspects of IPR, for which it might be 
interesting to detect what drives the actual IPR preference of open innovation firms. Given the exploratory empirical nature of our research and the small size of our sample, we will continue our analysis applying a simple model with a small number of variables to examine the possible relationship of these variables with the preference for IPR by open innovation firms. ${ }^{5}$ As nearly always with this line of research, there is a major concern of endogeneity which forces us to interpret most results in terms of association rather than effect.

Literature on the strategic, behavioural, and decision making aspects of open innovation differentiates between internal and external context characteristics (Huizingh, 2011; Lichtenthaler, Ernst, and Hoegl, 2010). In line with this literature, we suggest a small set of firm specific (internal) core factors and an environmental (external) factor that are associated with the preference for IPR by open innovation firms. More specifically, our model consists of three internal factors: the openness of firms, their absorptive capacity, and their legalistic attitude. The external factor refers to the competitive dynamics that open innovation firms face.

Laursen and Salter (2005) suggest that there is a direct relationship between the openness of a firm and its appropriability strategy. We expect that the degree of openness of firms, the extent to which they exchange their knowledge with others, will generate awareness with these firms as to the risk of unprotected knowledge exchange with a variety of partners. As being open to other firms involves substantial hazards, including knowledge leakage and misappropriation, IPR can be a useful measure of protection.

Also, the more firms engage in open innovation activities with a variety of other organizations such as suppliers, customers, competitors, universities and research institutes, and start-up firms, the more complex their network of knowledge exchange with multiple partners. The higher this complexity, the more these firms will need to control their knowledge exchange. In such a complex setting, IPR are seen as effective means to protect 
knowledge exchange between firms (Merges, 2006) and as such, we can expect that firms that are active in open innovation with a variety of partners will use IPR to protect their knowledge exchange. In other words, the more open firms are in terms of their external knowledge exchange, the higher their preference for IPR, see also Hurmelinna-Laukkanen (2011) and Luoma, Paasi, and Valkokari (2010).

Following suggestions by Laursen and Salter (2005), Lichtenthaler (2011) and Lichtenthaler and Lichtenthaler (2009), we expect the absorptive capacity of firms (Cohen and Levinthal, 1990) to impact the preference of firms for IPR. We understand the ability of firms to recognize the value of new information, to assimilate this new information and to turn this into actual innovations to indicate their absorptive capacity and also their innovative potential. In order to be able to develop this absorptive capacity, firms need to generate substantial prior related knowledge to understand the knowledge that is absorbed (Cohen and Levinthal, 1990; Jansen, van den Bosch, and Volberda, 2005). Therefore, this absorptive capacity not only signals the learning potential of open innovation firms themselves, it also indicates their relevance as a source of knowledge for others. Therefore, the higher this absorptive capacity of open innovation firms, the higher their innovative potential, the higher the risk that the knowledge that they share with their partners is appropriated by these partners, the higher their preference for IPR.

In the context of the absorptive capacity of open innovation firms as a source of knowledge for other firms, IPR can protect the knowledge exchange of open innovation firms. Also, we can expect that the higher the absorptive capacity of open innovation firms, the more interesting they are as open innovation partners to others. Hence, the more open innovation firms are aware of the risks of their absorptive capacity as they exchange knowledge with others, the more these firms are inclined to prefer IPR protection. 
As we have seen in the foregoing, open innovation firms have strong preference for formal contracts to govern their relationship with their open innovation partners. However, these firms still do differ to some extent with regard to the degree to which they value the importance of these contracts. The higher the importance of contracts for firms with open innovation partnerships, the more we can expect that this indicates the degree to which they perceive formal means of control, such as contracts, as a vital element of their business model. As such, this aspect of their business model reveals a legalistic attitude of firms that is not only related to contracts but we expect it to be also associated with the control of crucial firm knowledge through IPR. Following previous research (Luoma, Paasi, and Valkokari, 2010), we expect that the preference of open innovation firms for formal contractual protection methods in their inter-organizational partnerships is associated with a higher preference for IPR.

As an external factor, the competitive dynamics of firms' product markets is frequently seen as a major environmental driver of their propensity to enter into a range of partnerships with other firms (Oster, 1999, Powell, Koput, and Smith-Doerr, 1996). In markets where the competitive environment is subject to frequent changes, firms are more inclined to enter into partnerships with other firms, in search for new relevant knowledge. As indicated by Gassman and Henkel (2004), Ozman (2008) and Lichtenthaler, Ernst, and Hoegl (2010) this also applies to partnerships in the context of open innovation where competitive dynamics drives open innovation collaboration. Interestingly, these competitive dynamics in firms' product markets, where they face increased competition, are also found to be an important external contingency factor for their innovative performance that demands specific attention to IPR (Hausman and Leonard, 2006; Somaya, 2003). In the current context of open innovation, this suggests that higher levels of competitive dynamics in firms’ products markets affect their preference for IPR. The protection of open innovation firms' knowledge 
to be exchanged with their partners is of particular relevance in dynamic product markets where the competitive landscape and its players are changing rapidly. Under these conditions, where firms collaborate to improve their innovative performance, while facing increasing competition, they are expected to value IPR to protect the innovative knowledge that they exchange with a variety of partners. Hence, the higher levels of competitive dynamics in open innovation firms’ product markets, while sharing knowledge to improve their innovative performance, the higher their preference for IPR.

\section{Description of variables and measures}

Our dependent variable measures firms' perception of the importance of IPR in the context of open innovation through a summated scale of five 7 point Likert scale items. Respondents were asked to assess how important different intellectual property rights (patents, trademarks, copyrights, design rights, technical and commercial information (trade secrets)) are for protecting their innovative capabilities from their open innovation partner firms. Cronbach’s alpha for these five items is .81, which reveals strong reliability.

Openness of firms refers to the degree to which open innovation firms exchange their knowledge with a range of partners. We used the summated scale of eight items (suppliers, customers, competitors, universities/research institutes, innovation intermediaries, start-up firms, other firms, and new partners for competence development) to determine the extent to which firms conduct open innovation with a variety of partners (Cronbach's alpha $=.80$ ). Following Laursen and Salter (2006), we asked respondents to indicate to what extent they access different external knowledge sources concerning their innovation activities. Our measurement, at a 7 point Likert scale, was adapted to include some new external knowledge sources, such as 'innovation intermediaries' and 'start-up firms', which have been shown to 
be relevant to the context of open innovation (Chesbrough, 2006a,b; Christensen, Olesen, and Kjaer, 2005; Lichtenthaler, 2011).

Absorptive capacity was measured with three-items on 7 point Likert scales. These items assess to what extent firms translate external knowledge into concrete internal applications, to what extent it is integrated into new products or services, and to what extent external knowledge is exploited within firms' boundaries. Again, we used the summated scale of these three items. Cronbach’s alpha (.89) indicates strong reliability.

The legalistic attitude of open innovation firms was measured with a single item, which asks respondents to assess the importance of the legal implications of formal contracts for controlling the progress of collaboration with their open innovation partner firms on a 7 point Likert scale.

Competitive dynamics was measured through the extent to which firms indicated that their competitive environment is expected to change over the next five years. A dummy variable was created by collapsing 'less competitive' and 'similar level of competitiveness' into the category of low competitiveness, while the answer option 'more competitive' builds the category of high competitiveness.

Our analysis also includes a small set of control variables. To control for firm size, we included the logarithm of the number of employees. Given our cross-industry sample, we also control for industry effects. We grouped the sample firms into the following three classes: processing (including chemicals and food), manufacturing, and others. For the last two classes we included a dummy variable $(1=$ pertaining to this industry; $0=$ not pertaining to this industry). The same method was applied to control for the firm's country of origin, by including a dummy for US (0) versus non-US firms (1). 


\section{Results}

We used OLS regression models to analyse the relationship between the identified set of variables and the importance of IPR in the context of open innovation. Some descriptive statistics and the correlations are presented in table 6. Although the correlation between absorptive capacity and openness is relatively high, multicollinearity does not seem to pose a problem in our analysis. We calculated Variance Inflation Factors to check for potential multicollinearity and all values are close to 1 (with a highest value of 1.8) and, therefore, these values are within an acceptable range.

----- insert table 6 about here -----

Model 1 in table 7 presents the results for the basic model with the control variables, model 2 presents the full model with the core variables added to the control variables. ${ }^{6}$ Alternatively, starting with the basic model and adding one individual core variable at a time or subsequently adding core variables does not alter the results. It turns out that two internal factors, i.e., openness and legalistic attitude, are positively and significantly related to the relevance of IPR and so does competitive dynamics as the external determinant. Absorptive capacity and the control variables have no significant impact on the dependent variable.

----- insert table 7 about here -----

Due to our relatively small sample size, we have a limited number of observations per estimated parameter, which might lead to 'overfitting' the sample (Hair, Black, Babin, Anderson, and Tatham, 2006). In order to validate our results, we used bootstrapping as an alternative estimation procedure, which produces more accurate estimates for small sample 
sizes (Borwnstone and Valletta, 2001) (see the Appendix). The bootstrap analysis generates qualitatively similar results, the only difference is that 'competitive dynamics' becomes significant at the $5 \%$ level (see the table in the Appendix).

Together these findings indicate that the more open these open innovation firms are in terms of their external knowledge exchange, which does create a risk of unintended knowledge leakage, and the more legalistic their attitude, that expresses their preference for controlling their collaboration with others through contracts, the more relevant these firms perceive IPR as means to protect their knowledge exchange. Also, the more open innovation firms operate in product markets with higher levels of competitive dynamics, that express expected changes in competition, the more relevant they see their IPR protection. Hence, the preference for IPR in the context of open innovation is associated with managerial choice (openness and legalistic attitude) as well as conditioned by the external environment (competitive dynamics).

\section{Discussion and conclusions}

Our research indicates that in terms of the governance of their collaborative innovative activities, firms active in open innovation appear to follow a somewhat 'unadventurous' strategy. This strategy is much more in line with what could be expected according to wellaccepted organizational economics theory (e.g. Williamson, 1985) that is closer to Chesbrough (2006a,b) than to a more 'radical' open innovation approach, as advocated by Baldwin and von Hippel (2011), von Hippel and von Krogh (2006) and Pénin (2011). Rather than engaging in open disclosure and freely revealing their innovative activities to partners, firms seem to use formal contracts to organize their open innovation activities with specific partners. However, given the flexibility required by these innovative activities with a range of partners, where the objectives of collaboration might change over time, these open innovation 
contracts are probably not to be characterized as discrete, standard contracts but as subject to flexible private ordering (Almirall and Casadesus-Masanell, 2010; Hagedoorn and Hesen, 2007; Lee, Nystén-Haarala, and Huhtilaienen, 2010). Also, both the control and the monitoring dimension of contracts, the degree to which firms use contracts from a legal or from a practical process perspective, appear to be relevant for open innovation collaboration.

In line with those contributions that stress the role that IPR should play in open innovation (e.g. Dubiansky, 2006; Graham and Mowery, 2006; Pisano and Teece, 2007; Sandulli and Chesbrough, 2009) and unlike contributions that emphasize the need for only limited or no appropriability of open innovation activities (e.g. Pénin, 2011; von Hippel and von Krogh, 2003), firms active in open innovation appear to prefer to systematically protect their innovative capabilities from their open innovation partners. There are differences with regard to the degree to which separate elements of IPR are used by open innovation firms but the overall preference for using IPR is manifest across the board. In addition, IPR are relevant indicators of the innovative capabilities of firms and as such IPR can also signal the attractiveness of firms to their (potential) open innovation partners.

Although, our research is truly exploratory in nature and the objectives of our contribution are modest, we do make a first attempt to explain the preference of firms for IPR in the context of open innovation in terms of internal firm characteristics and more general external determinants. The openness of firms, i.e., the degree to which firms exchange their innovative knowledge with a variety of partners, their legalistic attitude, i.e., the importance they assign to formal contracting, and the dynamic competitive nature of their product market environment are associated with a higher preference for IPR. In general, this indicates that the more dynamic product market conditions play a role in the competitive environment of open innovation firms and the more importance these firms adhere to formal contractual relationships with their partners in combination with the open nature of their external 
knowledge sourcing, the more they are inclined to protect their innovative capabilities through IPR.

Finally, our research is based on two complementary approaches, a series of in-depth interviews and a survey, and it does provide us with some new insights, yet it also has some shortcomings. Most prominently: our sample is, despite several attempts to increase its size, relatively small which not only limits the extent to which we can analyse various firm and industry characteristics associated with open innovation, it also limits the degree to which we can generalize our findings. As such, our research is a modest contribution, albeit one of the first contributions, to a research agenda that empirically considers the governance of open innovation and the role of various legal and contractual implications of open innovation. Despite these limitations that come with the exploratory nature of our research, we are confident that our findings so far do reveal some interesting patterns and insights that can be used for further study of the implications of the current open innovation practice for the governance of inter-firm relationships and the use of IPR. 


\section{References}

Alexy, O., Criscuolo, P. and Salter A. (2009). Does IP strategy have to cripple open innovation? MIT Sloan Management Review, 51 (1), 71-77.

Almirall, E. and Casadesus-Masanell, R. (2010). Open versus closed innovation: A model of discovery and divergence. Academy of Management Review, 35 (1), 27-47.

Argyres, N.S., Mayer, K.J. (2007). Contract design as a firm capability: an integration of learning and transaction cost perspectives. Academy of Management Review, 32 (4), 1060-1077.

Baldwin, C. and von Hippel, E. (2011). Modeling a paradigm shift: from producer innovation to user and open collaborative innovation. Organization Science, 22 (6), 1399-1417.

Bianchi, M., Cavaliere, A., Chiaroni, D., Frattini, F., and Chiesa, V. (2011). Organizational modes for open innovation in the bio-pharmaceutical industry: an exploratory analysis. Technovation, 31 (1), 22-33.

Brownstone, D. and Valletta, R. (2001). The bootstrap and multiple imputations: Harnessing increased computing power for improved statistical tests. The Journal of Economic Perspectives, 15 (4), 129-141.

Chesbrough, H.W. (2003). Open Innovation: The new imperative for creating and profiting from technology, Boston, M.A.: Harvard Business School Press.

Chesbrough, H.W. (2006a). Open Innovation: A new paradigm for understanding industrial innovation. In Chesbrough, H.W., Vanhaverbeke, W. and West, J. (eds), Open Innovation: Researching a New Paradigm (pp. 1-12), Oxford: Oxford University Press.

Chesbrough, H. (2006b). Open business models: How to thrive in the new innovation landscape. Boston: Harvard Business School Press.

Christensen, J.F., Olesen, M.H., and Kjaer, J.S. (2005). The industrial dynamics of open 
innovation - Evidence from the transformation of consumer electronics. Research Policy, Vol. 34, 1533-1549.

Cohen, W.M., and Levinthal, D.A. (1990). Absorptive capacity: A new perspective on learning and innovation. Administrative Science Quarterly, 35 (1), 128-152.

Cohen, W.M., Nelson R.R., Walsh, J. P. (2000). Protecting their intellectual assets: Appropriability conditions and why U.S. manufacturing firms patent (or not), Cambridge (MA), National Bureau of Economic Research, working paper 7552

Creswell, J.W. and Plano-Clark, V.L. (2007). Designing and Conducting Mixed Methods Research. Thousand Oaks: C.A.: Sage.

Dahlander, L and Gann, D.M. (2010). How open is innovation? Research Policy, 39, 699709.

De Backer, K., López-Bassols, K.V. and Martinez, C. (2008). Open innovation in a global perspective: what do existing data tell us? OECD Science, Technology and Industry working papers, 2008/4, OECD Publishing, OECD, Paris.

De Laat, P.B. (2005). Copyright or copyleft? An analysis of property regimes for software development. Research Policy, 34, 1511-1532.

Dillmann, D.A. (2007). Mail and internet surveys: the tailored design method ( $2^{\text {nd }}$ ed.) John Wiley \& Sons: New Jersey.

Dubiansky, J. (2006). The role of patents in fostering open innovation. Virginia Journal of Law \& Technology, 11 (7), 1-36.

Enkel, E., Gassmann, O., and Chesbrough, H. (2009). Open R\&D and open innovation: exploring the phenomenon. $R \& D$ Management, 39 (4), 311-316.

Fey, C.F. and Birkinshaw, J. (2005). External sources of knowledge, governance mode, and R\&D performance. Journal of Management, 31 (4), 597-621.

Gassmann, O. and Enkel, E. (2004). Towards a theory of open innovation: Three core process 
archetypes. Paper presented at RADMA conference, Lisbon (Portugal).

Graham, S.J.H. and Mowery, D.C. (2006). The use of intellectual property in software: implications for open innovation. In Chesbrough, H.W., Vanhaverbeke, W. and West, J. (eds), Open innovation: researching a new paradigm, Oxford University Press, Oxford, pp 109-133.

Grimpe, C. and Sofka, W. (2009). Search patterns and absorptive capacity: Low- and high-technology sectors in European countries. Research Policy, 38, 495-506.

Hagedoorn, J., Hesen, G. (2007). Contract law and the governance of inter-firm technology partnerships. An analysis of different modes of partnering and their contractual implications. Journal of Management Studies, 44 (3), 342-366.

Hair, J.F., Black, W.C., Babin, B.J., Anderson, R.E. and Tatham, R.L. (2006). Multivariate Data Analysis. Upper Saddle River, New Jersey: Pearson Prentice Hall.

Hall, B., Jaffe, A., and Trajtenberg, M. (2005). Market value and patent citations. Rand Journal of Economics, 36: 16-38.

Hausman, J. and Leonard, G. (2006). Real options and patent damages: The legal treatment of non-infringing alternatives, and incentives to innovate. Journal of Economic Surveys, $20(4), 493-512$.

Henkel, J. (2006). Selective revealing in open innovation processes: The case of embedded Linux. Research Policy, 35, 953-969.

Huizingh, E.K.R.E. (2011). Open innovation: State of the art and future perspectives. Technovation, 31, 2-9.

Hurmelinna-Laukkanen, P. (2011). Enabling collaborative innovation - knowledge protection for knowledge sharing. European Journal of Innovation Management, 14 (3), 303321.

Jansen, J.J.P., van den Bosch, F.A.J. and Volberda, H.W. (2005). Managing potential and 
realized absorptive capacity: how do organizational antecedents matter? Academy of Management Journal, 48, 999-1015.

Keupp, M.M. and Gassmann, O. (2009). Determinants and archetype users of open innovation. R\&D Management, 12 (1), 7-19.

Kirschbaum, R. (2005). Open innovation in practice. Research Technology Management, July-August, 2005.

Laursen, K. and Salter, A. (2005). The paradox of openness - Appropriability and the use of external sources of knowledge for innovation. Working paper, Copenhagen Business School

Laursen, K. and Salter, A. (2006). Open for innovation: the role of openness in explaining innovation performance among U.K. manufacturing firms. Strategic Management Journal, 27,131-150.

Lee, N. (2009). Exclusion and coordination in collaborative innovation and patent law. International Journal of Intellectual Property Management, 3 (1), 79-93.

Lee, N., Nystén-Haarala, S., and Huhtilaienen, L (2010). Interfacing intellectual property rights and open innovation, Lappeenranta University of Technology, Department of Industrial Management, Research Report No. 225.

Lee, S., Park. G., Yoon, B., and Park, J. (2010). Open innovation in SMEs - An intermediated network model. Research Policy, 39, 290-300.

Lichtenthaler, U. (2008). Externally commercializing technology assets: An examination of different process stages. Journal of Business Venturing, 23, 445-464.

Lichtenthaler, U. (2011). Open innovation: past research, current debates, and future directions. Academy of Management Perspectives, February, 75-93.

Lichtenthaler, U. and Ernst, H. (2009). Opening up the innovation process: the role of technology aggressiveness. $R \& D$ Management, 39(1), 38-54. 
Lichtenthaler, U., Ernst, H., and Hoegl, M. (2010). Not-sold-here: how attitudes influence external knowledge exploitation. Organization Science, 21 (5), 1054-1071.

Lichtenthaler, U. and Lichtenthaler, E. (2009). A capability-based framework for open innovation: Complementing absorptive capacity. Journal of Management Studies, 46 (8), 1315-1338.

Luoma, T., Paasi, J., and Valkokari, K. (2010). Intellectual property in inter-organisational relationships - findings from an interview study. International Journal of Innovation Management, 14 (3), 399-414.

Macaulay, S. (1963). Non-contractual relations in business: a preliminary study. American Sociological Review 28, 1-19.

Mellewigt, T., Madhok, A., Weibel, A. (2007). Trust and formal contracts in interorganizational relationships - substitutes and complements. Managerial and Decision Economics, 28, 833-847.

Merges, R.P. (2006). A transactional view of property rights, Berkeley Technology Law Journal, 20, 1477-1520.

Miles, M.B. and Huberman, A.M. (1994). Qualitative Data Analysis. (2 ${ }^{\text {nd }}$ ed.) Thousand Oaks: C.A.: Sage.

Munsch, K. (2009). Open model innovation. Research Technology Management, May-June.

Oster, S.M. (1999). Modern competitive analysis. Oxford University Press, New York.

Ozman, M. (2008). The two faces of open innovation: Network externalities and learning. Working paper: Bureau d'Economie Appliquée.Paris

Pénin J. (2011). Open source innovation: Towards a generalization of the open source model beyond software. Revue d'Economie Industrielle (in press)

Pisano, G.P. and Teece, D.J. (2007). How to capture value from innovation: Shaping 
intellectual property and industry architecture. California Management Review, 50 (1), 278-295.

Podsakoff, P.M., MacKenzie, S.B., Lee, J.Y., and Podsakoff, N.P. (2003). Common method biases in behavioural research: A critical review of the literature and recommended remedies. Journal of Applied Psychology, 88 (5), 879-903.

Powell, W.W., Kopu, K., and Smith-Doerr, L. (1996) Interorganizational collaboration and the locus of innovation; networks of learning in biotechnology. Administrative Science Quarterly. 41, 116-145.

Punch, K.F. (2005). Introduction to Social Research. Quantitative and Qualitative Approaches ( $2^{\text {nd }}$ ed.) London: Sage.

Reuer, J.J., Ariño, A. (2007). Strategic alliance contracts: dimensions and determinants of contractual complexity. Strategic Management Journal, 28, 313-330.

Sandulli, F. and Chesbrough, H. (2009) The two faces of open business models. Working Paper Available at SSRN: http://ssrn.com/abstract=1325682

Somaya, D. (2003). Strategic determinants of decisions not to settle patent litigation. Strategic Management Journal, 24, 17-38.

Von Hippel, E. and von Krogh, G. (2003). Open source software and the "private-collective” innovation model: Issues for organization science. Organization Science, 14 (2), 209223.

Von Hippel, E. and Von Krogh, G. (2006). Free revealing and the private-collective model for innovation incentives. R\&D Management, Vol. 36, 295-306.

West, J. (2006). Does appropriability enable or retard open innovation? In Chesbrough, H.W., Vanhaverbeke, W. and West, J. (eds), Open innovation: Researching a new paradigm, Oxford University Press, Oxford, pp 109-133.

Williamson, O.E. (1985). The economic institutions of capitalism. The Free Press, New York. 
Table 1 Distribution of industries for sample of open innovation firms $(n=86)$

\begin{tabular}{|l|c|}
\hline Industries: & \\
\hline Chemicals & $36.0 \%$ \\
\hline Electronics & $12.8 \%$ \\
\hline Food & $5.8 \%$ \\
\hline Transportation equipment & $4.7 \%$ \\
\hline Metals & $3.5 \%$ \\
\hline Measuring, analysing, and control instruments & $3.5 \%$ \\
\hline & $1.2 \%$ \\
\hline Other manufacturing & $12.8 \%$ \\
\hline Communications & \\
\hline & \\
\hline Total & \\
\hline
\end{tabular}


Table 2 Distribution of sample of open innovation firms in size classes $(n=86)$

\begin{tabular}{|l|c|}
\hline Size classes (number of employees) & \\
\hline$<100$ & $12.8 \%$ \\
\hline $100-999$ & $8.1 \%$ \\
\hline $1,000-4,999$ & $4.7 \%$ \\
\hline $5,000-9,999$ & $7.0 \%$ \\
\hline $10,000-49,999$ & \\
\hline Total & $29.1 \%$ \\
\hline & \\
\hline & \\
\hline & \\
\hline
\end{tabular}


Table 3 Importance of contracts for monitoring or controlling open innovation partners, scores on 7 point Likert scales $(\mathrm{n}=86)$

\begin{tabular}{|l|c|c|}
\hline & Mean & $\begin{array}{c}\text { Standard } \\
\text { deviation }\end{array}$ \\
\hline $\begin{array}{l}\text { Practical (monitoring) importance of contracts with } \\
\text { open innovation partners }\end{array}$ & 5.10 & 1.567 \\
\hline $\begin{array}{l}\text { Legal (controlling) importance of contracts with open } \\
\text { innovation partners }\end{array}$ & 5.42 & 1.516 \\
\hline
\end{tabular}


Table 4 Share of open innovation firms that perceive intellectual property rights as relevant for the protection or signalling of innovative capabilities, \% for protection and for signalling, relevance is indicated by a score of 5 or higher on 7 point Likert scale $(n=86)$

\begin{tabular}{|c|c|c|}
\hline & Protection & Signalling \\
\hline Patents & $89.5 \%$ & $79.1 \%$ \\
\hline Trademarks & $74.7 \%$ & $61.0 \%$ \\
\hline Copyrights & $53.1 \%$ & $39.7 \%$ \\
\hline Design rights & $66.7 \%$ & $53.8 \%$ \\
\hline $\begin{array}{l}\text { Technical or commercial information } \\
\text { (trade secrets) }\end{array}$ & $89.4 \%$ & $78.6 \%$ \\
\hline
\end{tabular}


Table 5 Importance of IPR for protection or signalling for open innovation firms, scores on 7 point Likert scales $(n=86)$

\begin{tabular}{|l|c|c|}
\hline \multicolumn{1}{|c|}{ Protection } & Mean & $\begin{array}{c}\text { Standard } \\
\text { deviation }\end{array}$ \\
\hline \multicolumn{1}{|c|}{} & & \\
\hline Importance of patents & 6.28 & 1.460 \\
\hline Importance of trademarks & 5.41 & 1.638 \\
\hline Importance of copyrights & 4.63 & 1.854 \\
\hline Importance of design rights & 4.98 & 1.830 \\
\hline $\begin{array}{l}\text { Importance of technical or commercial information } \\
\text { (trade secrets) }\end{array}$ & 6.04 & 1.258 \\
\hline & & \\
\hline \multicolumn{1}{|c|}{} & & 1.761 \\
\hline Importance of patents & 5.71 & 1.862 \\
\hline Importance of trademarks & 4.84 & 1.966 \\
\hline Importance of copyrights & 3.92 & 1.863 \\
\hline Importance of design rights & 5.46 & \\
\hline $\begin{array}{l}\text { Importance of technical or commercial information } \\
\text { (trade secrets) }\end{array}$ & 5.61 & \\
\hline & & \\
\hline
\end{tabular}


Table 6 Correlation table $(\mathrm{n}=86)$

\begin{tabular}{|l|l|l|l|l|l|l|l|l|l|l|}
\hline & Mean & $\begin{array}{l}\text { Standard } \\
\text { deviation }\end{array}$ & IPR & Non-US & $\begin{array}{l}\text { Manufac- } \\
\text { turing }\end{array}$ & $\begin{array}{l}\text { Other } \\
\text { industries }\end{array}$ & Size & Openness & $\begin{array}{l}\text { Absorptive } \\
\text { capacity }\end{array}$ & $\begin{array}{l}\text { Legalistic } \\
\text { attitude }\end{array}$ \\
\hline IPR & 5.56 & 1.29 & & & & & & & \\
\hline Non-US & 0.74 & 0.44 & -.089 & & & & & & \\
\hline Manufacturing & 0.38 & 0.49 & .054 & .133 & & & & & & \\
\hline Other industries & 0.19 & 0.40 & $-.309^{* * *}$ & .082 & $-.381^{* * *}$ & & & & \\
\hline Size & 9.15 & 3.07 & .175 & $-.236^{* *}$ & .102 & $-.279^{* * *}$ & & & \\
\hline Openness & 4.47 & 1.02 & $.366^{* * *}$ & -.019 & -.053 & -.072 & $.198^{* *}$ & & & \\
\hline $\begin{array}{l}\text { Absorptive } \\
\text { capacity }\end{array}$ & 4.93 & 1.20 & $.287^{* * *}$ & -.013 & -.049 & -.047 & -.054 & $.628^{* *}$ & & \\
\hline Legalistic attitude & 5.46 & 1.53 & $.352^{* * *}$ & $-.326^{* * *}$ & -.064 & $-.271^{* * *}$ & .111 & .011 & -.033 & \\
\hline $\begin{array}{l}\text { Competitive } \\
\text { dynamics }\end{array}$ & 0.74 & 0.44 & $.269^{* * *}$ & .015 & $.244^{* *}$ & -.125 & .040 & .125 & .090 & .011 \\
\hline
\end{tabular}

* significant at $10 \%$; ** significant at $5 \%$ level, *** significant at $1 \%$ level 
Table 7 Results of OLS analysis $(n=86)$

\begin{tabular}{|c|c|c|}
\hline & Model 1 & Model 2 \\
\hline \multirow[t]{2}{*}{ Non-US } & -.096 & .128 \\
\hline & $(.311)$ & $(.305)$ \\
\hline \multirow[t]{2}{*}{ Manufacturing } & -.171 & -.097 \\
\hline & $(.296)$ & $(.288)$ \\
\hline \multirow[t]{2}{*}{ Other industries } & $-.964 * *$ & -.571 \\
\hline & $(.374)$ & $(.367)$ \\
\hline \multirow[t]{2}{*}{ Size } & .036 & .024 \\
\hline & $(.046)$ & $(.045)$ \\
\hline \multirow[t]{2}{*}{ Openness } & & $.282 *$ \\
\hline & & $(.163)$ \\
\hline \multirow[t]{2}{*}{ Absorptive capacity } & & .130 \\
\hline & & $(.136)$ \\
\hline \multirow[t]{2}{*}{ Legalistic attitude } & & $.245^{* * *}$ \\
\hline & & $(.090)$ \\
\hline \multirow[t]{2}{*}{ Competitive dynamics } & & $.558 *$ \\
\hline & & $(.292)$ \\
\hline $\mathrm{R}^{2}$ & .110 & .341 \\
\hline $\mathrm{R}^{2}$ adjusted & .065 & .262 \\
\hline $\mathrm{F}$ & 1.75 & $4.34 * * *$ \\
\hline
\end{tabular}

* significant at $10 \%$; ** significant at $5 \%$ level; *** significant $1 \%$ Standard errors in brackets 


\section{Appendix - Bootstrapping Analysis}

Bootstrapping can be used for validating a multivariate model by drawing a large number of subsamples - with replacement from the original observed data - and estimating models for each subsample (Hair, Black, Babin, Anderson, and Tatham, 2006). The estimates from these subsamples are then combined to derive coefficients and standard errors. For small sample sizes the bootstrap approximation should be more accurate than standard large-sample analytical techniques (Brownstone and Valletta, 2001). The table below displays the results of the bootstrap (with 100 replications). As bootstrapping is not compatible with pairwise deletion or multiple imputation, we used listwise deletion of missing values and ran the analysis on a sample of $n=76$.

Results of bootstrap analysis $(\mathrm{n}=76)$

\begin{tabular}{|lccc|}
\hline & $\begin{array}{c}\text { Observed } \\
\text { coefficients }\end{array}$ & $\begin{array}{c}\text { Bootstrap } \\
\text { standard errors }\end{array}$ & p-values \\
& & & \\
Non-US & .163 & .275 & .552 \\
Manufacturing & -.271 & .294 & .358 \\
Other industries & -.517 & .366 & .158 \\
Size & .054 & .041 & .182 \\
& & & \\
Openness & $.290^{*}$ & .151 & .055 \\
Absorptive capacity & .174 & .149 & .244 \\
Legalistic attitude & $.259^{* * *}$ & .097 & .008 \\
Competitive dynamics & $.606 * *$ & .263 & .021 \\
\hline
\end{tabular}

\footnotetext{
* significant at $10 \%$; ** significant at $5 \%$ level; *** significant $1 \%$
} 
${ }^{1}$ Open innovation cooperation refers to collaboration of firms with a range of partners (firms and other organizations and institutions). In the context of our current exploratory empirical contribution, we prefer to focus on inter-firm open innovation and to leave more complex contractual and IPR issues that refer to a much wider range of inter-organizational relationships for future study.

${ }^{2}$ See Eurostat Community Innovation Statistics, 2008 and US National Science Foundation/Division of Science Resources Statistics, Business R\&D and Innovation Survey, 2008.

${ }^{3}$ A paired samples t-test, based on the Fisher Exact test that is equivalent to a Chi-square test but more appropriate for small sample sizes, indicates this marginally significant difference ( $p$-value $=0.081$ ) between the use of contracts for controlling purposes (5.42) and monitoring purposes (5.10).

${ }^{4}$ Under ' copyleft' conditions, any invention can freely be used by others but it is required that all modified and extended versions of the invention are free as well.

${ }^{5}$ Given our sample size ( $n=86$ ), we are very limited in terms of the number of variables to be included in the statistical analysis. In addition, some potential variables were not included as they are highly correlated with other variables. Moreover, using most of these potential variables would, due to missing values, decrease the sample size even further.

${ }^{6}$ As some of the independent variables had missing values, we adopted several approaches for dealing with these missing values. Table 7 displays the OLS results with pairwise deletion. Listwise deletion $(\mathrm{n}=76)$ and multiple imputation generated qualitatively similar results, with the exception of 'competitive dynamics' which became significant at the $5 \%$ level. 


\section{The UNU-MERIT WORKING Paper Series}

2012-01 Maastricht reflections on innovation by Luc Soete

2012-02 A methodological survey of dynamic microsimulation models by Jinjing Li and Cathal O'Donoghue

2012-03 Evaluating binary alignment methods in microsimulation models by Jinjing Li and Cathal O'Donoghue

2012-04 Estimates of the value of patent rights in China by Can Huang

2012-05 The impact of malnutrition and post traumatic stress disorder on the performance of working memory in children by Elise de Neubourg and Chris de Neubourg

2012-06 Cross-national trends in permanent earnings inequality and earnings instability in Europe 1994-2001 by Denisa Maria Sologon and Cathal O'Donoghue

2012-07 Foreign aid transaction costs by Frieda Vandeninden

2012-08 A simulation of social pensions in Europe by Frieda Vandeninden

2012-09 The informal ICT sector and innovation processes in Senegal by Almamy Konté and Mariama Ndong

2012-10 The monkey on your back?! Hierarchical positions and their influence on participants' behaviour within communities of learning by Martin Rehm, Wim Gijselaers and Mien Segers

2012-11 Do Ak models really lack transitional dynamics? by Yoseph Yilma Getachew

2012-12 The co-evolution of organizational performance and emotional contagion by $\mathrm{R}$. Cowan, N. Jonard, and R.Weehuizen

2012-13 "Surfeiting, the appetite may sicken": Entrepreneurship and the happiness of nations by Wim Naudé, José Ernesto Amorós and Oscar Cristi

2012-14 Social interactions and complex networks by Daniel C. Opolot

2012-15 New firm creation and failure: A matching approach by Thomas Gries, Stefan Jungblut and Wim Naudé

2012-16 Gains from child-centred Early Childhood Education: Evidence from a Dutch pilot programme by Robert Bauchmüller

2012-17 Highly skilled temporary return, technological change and Innovation: The Case of the TRQN Project in Afghanistan by Melissa Siegel and Katie Kuschminder

2012-18 New Technologies in remittances sending: Opportunities for mobile remittances in Africa Melissa Siegel and Sonja Fransen

2012-19 Implementation of cross-country migration surveys in conflict-affected settings: Lessons from the IS Academy survey in Burundi and Ethiopia by Sonja Fransen, Katie Kuschminder and Melissa Siegel

2012-20 International entrepreneurship and technological capabilities in the Middle East and North Africa by Juliane Brach and Wim Naudé

2012-21 Entrepreneurship, stages of development, and industrialization by Zoltan J. Ács and Wim Naudé

2012-22 Innovation strategies and employment in Latin American firms by Gustavo Crespi and Pluvia Zuniga

2012-23An exploration of agricultural grassroots innovation in South Africa and implications for innovation indicator development by Brigid Letty, Zanele Shezi and Maxwell Mudhara

2012-24 Employment effect of innovation: microdata evidence from Bangladesh and Pakistan by Abdul Waheed 
2012-25 Open innovation, contracts, and intellectual property rights: an exploratory empirical study by John Hagedoorn and Ann-Kristin Ridder 